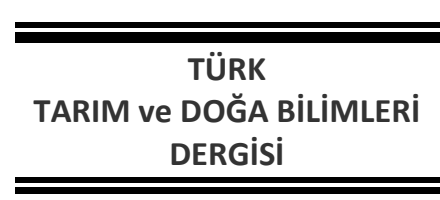

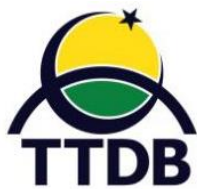

www.dergipark.gov.tr/turkjans

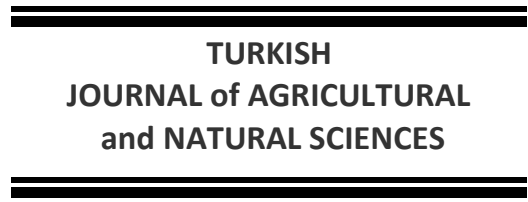

Araştırma Makalesi

\title{
Samsun İlinde Süt Sığırcılığı Yapan İşletmelerin Yapısal Özellikleri
}

\author{
Osman KILIÇ⿻ ${ }^{*}$ Gamze AYDIN ERYILMAZ² \\ ${ }^{1}$ Ondokuz Mayıs Üniversitesi, Ziraat Fakültesi, Tarım Ekonomisi Bölümü, Samsun \\ ${ }^{2}$ Ondokuz Mayıs Üniversitesi, Samsun Meslek Yüksekokulu, Park ve Bahçe Bitkileri Bölümü, Samsun \\ *Sorumlu Yazar: okilic@omu.edu.tr
}

Geliş Tarihi: 31.01.2020 Düzeltme Geliş Tarihi: 05.06.2020 Kabul Tarihi: 08.06.2020

\begin{abstract}
$\overline{\mathrm{O} z}$
Araştırmanın amacı, süt sığırcılığı yapan işletmelere ait yapısal özelliklerin belirlenmesidir. Veriler, Samsun ili Bafra ve Canik ilçelerinde süt sığırcılığı yapan 70 işletmeden anket yoluyla elde edilmiştir. Araştırma sonuçlarına göre, işletmelerin süt sığırcılığıyla ilgili en önemli sorunu \%51.4 ile süt fiyatındaki istikrarsılıktır. Bunu yem temini (\%41.4) ve pazarlama (\%37.1) sorunları izlemektedir. İşletmelerin \%37.2'si sığır sayısını artırmayı düşünürken, \%51.4'ü mevcut yapılarıyla süt sığırcılığına devam etmek istemektedir. İşletme yöneticilerinin \%11.4'ü süt sığırcılığına devam etmeyi düşünmemektedir. Buna gerekçe olarak; sermaye kısıtıığı (\%37.5), gelir yetersizliği (\%25), hayvan bakımındaki zorluklar (\%25) ve işgücü eksikliği (\%12.5) gösterilmiştir. Süt sığırcılı̆̆ı yapan işletmelerin ekonomik anlamda sürdürülebilirliği, büyük ölçüde yapısal özellikler yönünden yeterli donanıma sahip olmalarına bağlıdır. Bu amaçla süt sığırcılığı yapan işletmelere ait yapısal özelliklerin iyileştirilmesinde, bölgesel farklılıklar ile işletme büyüklük gruplarını dikkate alan politikaların geliştirilmesine ihtiyaç vardır.
\end{abstract}

Anahtar kelimeler: Süt sığırcılığı, hayvan yetiştiriciliği, yapısal özellikler, Samsun, Türkiye

\begin{abstract}
Structural Characteristics of Dairy Cattle Farms in Samsun Province
Abstract

This research aims to determine the structural characteristics of dairy cattle farms. Data were obtained from 70 dairy cattle farms in the Bafra and Canik districts of Samsun Province. According to the results of the research, the most important problem of dairy cattle farms is the instability of milk price with $51.4 \%$. This is followed by feed supply (41.4\%) and marketing (37.1\%) problems. While $37.2 \%$ of the farms aim to increase cattle number, $51.4 \%$ of them want to continue dairy cattle activity with their existing structures. Of the total farmers, $11.4 \%$ are considering to not continue dairy cattle activity. The reasons for this decision are the shortage of capital (37.5\%), insufficient income (25\%), difficulties in animal care (25\%), and lack of labor (12.5\%). The economic sustainability of dairy cattle farms extremly depends on the fact that they are adequately equipped with structural features. For this purpose, policies taking into account regional differences and farm size groups, need to be developed in order to improve the structural characteristics of dairy cattle farms.
\end{abstract}

Key words: Dairy cattle, animal husbandry, structural characteristics, Samsun, Turkey

Giriş

Hayvancılık sektörü; hayvansal ürün ihtiyacının karşılanması, bitkisel üretim faaliyetleriyle karşılıklı girdi transferinin yapılması, sanayiye hammadde sağlanması, ihracat yoluyla döviz gelirlerinin artırılması, istihdam olanaklarının genişletilmesi ve mera alanlarının değerlendirilerek katma değer artışının sağlanması gibi birçok öneme sahiptir. Hayvancılığın kırsal kalkınma sürecinde ülkeleri uluslararası rekabette öne çıkaran bir sektör olması, işletme odaklı bölgesel hedefler ile makro düzeydeki politikaları önemli hale getirmektedir. Gelişmekte olan ülkelerde 
hayvancılıkla ilgili politikalarda daha çok yeterli ve dengeli beslenmenin sağlanması amaçlanırken, gelişmiş ülkelerde sosyal ve çevresel açıdan sürdürülebilir bir kırsal kalkınma modelinin gerçekleştirilmesi öncelikli hedefler arasında yer almaktadır. Sosyoekonomik yapısı ve coğrafi özellikleri itibariyle önemli bir tarımsal potansiyele sahip olan Türkiye'de hayvancılık, bitkisel üretimin yanında büyük ölçüde ikincil bir faaliyet olarak değerlendirilmektedir (Hozman ve Akçay, 2016). Öyle ki son yıllarda gelişmiş ülkelerde hayvansal üretimin toplam tarımsal üretim içindeki payı artarken, Türkiye'de böyle bir artış söz konusu değildir (Anonim, 2018a). Türkiye'de hayvancılık işletmelerinin yeterli teknik donanıma sahip olmamaları, girdi fiyatlarındaki dalgalanmalar ve artan uluslararası rekabet koşulları gibi nedenler, hayvancılık sektörünün devletin planlayıcı ve yol gösterici rolüne olan ihtiyacını artırmaktadır. Ancak Türkiye'de tarımsal destekleme politikaları oluşturulurken, bitkisel ve hayvansal üretim arasında denge kurulamamış, destekler çoğunlukla bitkisel üretimin artırılması ve kalitenin iyileştirilmesine yönelik verilmiştir (Saçlı, 2007). Türkiye'de hayvansal üretim için gerekli olan altyapı ve mevzuat çalışmalarına ise daha çok Avrupa Birliği $(A B)^{\prime}$ ne uyum sürecinde ağırlık verilmeye başlanmıştır. Günümüzde hayvancılığa yönelik ulusal politikalar, yalnızca yerel ihtiyaçlara göre şekillenmemekte, aynı zamanda uluslararası ticari anlaşmalar ve çeşitli organizasyonlar ile komşu ve lider ülkelerin eğilim ve uygulamalarından da önemli düzeyde etkilenmektedir (Can, 2018).

Türkiye'de hayvancılığın temel ve önemli faaliyet alanlarından biri süt sığırcılığı olup, süt üretiminin de büyük bir kısmı sığırlardan elde edilmektedir. Türkiye'de süt sığırcılığı, birkaç süt ineğine sahip küçük işletmelerde aile tüketimine yönelik yapılmasına rağmen, büyük ölçekli ticari işletmelerde daha çok yüksek kâr beklentisiyle yapılan önemli bir faaliyettir. Türkiye'nin 2018 yılındaki sığır varlığı yaklaşık 17 milyon baş olup, bunun 6.3 milyonu sağılan ineklerden oluşmaktadır. Aynı yıla ait 20 milyon ton olan süt üretiminin \%90.6'sı ineklerden elde edilmiştir (Anonim, 2018b). Hayvan başına süt verimi yıllar itibariyle bütün türlerde artmış olmakla birlikte, en büyük gelişmenin inek sütünde olduğu görülmektedir. Sağılan inek başına süt verimi 2013 yılında $2970 \mathrm{~kg}$ iken, beş yılda yaklaşık \%6.4 artarak 2018 yılında 3161 kg'a çıkmıştır. Bu değer, inek başına yıllık süt verimi $6000 \mathrm{~kg} \prime$ ın üzerinde olan $A B$ ülkeleriyle karşılaştırıldığında oldukça düşüktür (Anonim, 2018c). Sığırların veriminde, genetik faktörlerin yanı sıra bakım, besleme, barınak koşulları ve sürü yönetimiyle ilgili çevresel faktörlerin de etkisi söz konusudur (Alkan ve Ünlü, 2019). Bu bağlamda süt sığırcılığı işletmelerinde, verim ve kaliteyi etkileyen faktörlerin iyileştirilmesine yönelik araştırmalar büyük önem taşımaktadır. Süt sığırcılığının yerel, bölgesel ve ülkesel olarak ekonomiye olan katkısının artırılması için, öncelikle mevcut sorunların tespit edilmesi önemlidir.

Türkiye'nin farklı bölgelerinde yapılan araştırmalarda, süt sığırcılığı yapan işletmelerin yapısal özellikleri ve sorunları ele alınmıştır (Şahin, 2001; Tugay ve Bakır, 2009; Kaygısız ve ark., 2010; Şeker ve ark., 2012; Boz, 2013; Daş ve ark., 2014; Özyürek ve ark., 2014; Hozman ve Akçay, 2016; Alkan ve Ünlü, 2019; Bakır ve Kibar, 2019). Süt sığırcılığının çeşitli yönleriyle ele alındığı bu araştırmaların sonuçları, Türkiye'de süt sığırcılığı işletmelerindeki geleneksel üretim yapısının verim, kalite ve pazarlama gibi teknik konularla ilgili birçok soruna yol açtığını göstermektedir. Türkiye'de süt sığırcılığı işletmelerinin yapısal özellikleri ve sorunları, bölgelere ve illere göre büyük farklılıklar göstermektedir. Bu amaçla sürdürülebilir bir büyüme elde etmek için, yerel düzeyde yapılacak araştırmalarla süt sığırcılığıyla ilgili yapısal sorunlar tespit edilmeli ve uygulamaya dönük çözüm odaklı önlemler alınmalıdır. Bu araştırmanın amacı, Samsun ili Bafra ve Canik ilçelerinde süt sığırcılığı yapan işletmelere ait yapısal özellikleri ve yetiştiricilikle ilgili uygulamaları ortaya koymak, ayrıca mevcut yapının iyileştirilmesine ve sürdürülebilir bir üretim modelinin gerçekleştirilmesine yönelik çözüm önerileri geliştirmektedir.

\section{Materyal ve Yöntem}

Araştırmanın materyalini, Samsun ili Bafra ve Canik ilçelerinde süt sığırcılığı yapan işletmelerle 2019 yılında yapılan anketlerden elde edilen veriler oluşturmaktadır. Örnekleme birimi olarak, işletmelerdeki süt sığırı sayısı esas alınmıştır. Ana kitleyi oluşturan işletmeler; 1-6 baş, 7-20 baş ve 20 baştan fazla süt sığırına sahip işletmeler şeklinde üç gruba ayrılmıştır. Buna göre anket yapılan işletme sayısı, tabakalı tesadüfi örnekleme yöntemiyle 70 olarak belirlenmiştir (Yamane, 1967). Her bir gruba 
giren işletme sayısı ise oransal dağılıma göre; birinci grupta 21, ikinci grupta 32 ve üçüncü grupta 17 olarak tespit edilmiştir. Anketlerde; yöneticiye ait cinsiyet, yaş, eğitim, süt sığırcılığı deneyimi, sosyal güvence, çiftçilik dışındaki meslek ve tarımsal örgüt üyeliği ile nüfus varlığı, tarımsal faaliyet, sütün pazarlanması, süt sığırcılığının yapılma nedenleri, yatırım planları ve süt sığırcılığıyla ilgili sorunlara yer verilmiştir.

\section{Bulgular ve Tartışma}

Anket yapılan yöneticilerin \%91.4'ü erkek, \%8.6'sı ise kadındır. İşletmelerde 50 yaşın altındaki yöneticiler \%76.5 ile en fazla üçüncü gruptaki işletmelerde yer almaktadır. Aynı şekilde üçüncü grup işletmelerde yer alan yöneticilerde ilkokul mezunu üzerindeki okullaşma oranı en yüksektir (Çizelge 1).

Çizelge 1. İşletme yöneticilerine ait özellikler

\begin{tabular}{|c|c|c|c|c|c|c|c|c|}
\hline & \multicolumn{2}{|c|}{ 1. grup } & \multicolumn{2}{|c|}{ 2. grup } & \multicolumn{2}{|c|}{ 3. grup } & \multicolumn{2}{|c|}{$\begin{array}{l}\text { İşletmeler } \\
\text { ortalaması }\end{array}$} \\
\hline & Sayı & $(\%)$ & Sayı & (\%) & Sayı & (\%) & Sayı & (\%) \\
\hline \multicolumn{9}{|l|}{ Cinsiyet } \\
\hline Kadın & 5 & 24 & - & - & 1 & 5.9 & 6 & 8.6 \\
\hline Erkek & 16 & 76 & 32 & 100 & 16 & 94 & 64 & 91 \\
\hline Toplam & 21 & 100 & 32 & 100 & 17 & 100 & 70 & 100 \\
\hline \multicolumn{9}{|l|}{ Yaş } \\
\hline$<50$ & 12 & 57 & 18 & 56 & 13 & 77 & 43 & 61 \\
\hline $50-65$ & 7 & 33 & 13 & 41 & 4 & 24 & 24 & 34 \\
\hline$>65$ & 2 & 9.5 & 1 & 3.1 & - & - & 3 & 4.3 \\
\hline Toplam & 21 & 100 & 32 & 100 & 17 & 100 & 70 & 100 \\
\hline \multicolumn{9}{|l|}{ Eğitim } \\
\hline illkokul & 14 & 67 & 21 & 66 & 7 & 41 & 42 & 60 \\
\hline Ortaokul & 2 & 9.5 & 5 & 16 & 6 & 35 & 13 & 19 \\
\hline Lise & 4 & 19 & 6 & 19 & 3 & 18 & 13 & 19 \\
\hline Üniversite & 1 & 4.8 & - & - & 1 & 5.9 & 2 & 2.8 \\
\hline Toplam & 21 & 100 & 32 & 100 & 17 & 100 & 70 & 100 \\
\hline \multicolumn{9}{|l|}{ Süt sığırcılığı deneyimi } \\
\hline$<14$ & 9 & 43 & 7 & 22 & 3 & 18 & 19 & 27 \\
\hline $14-36$ & 7 & 33 & 16 & 50 & 10 & 59 & 33 & 47 \\
\hline$>36$ & 5 & 24 & 9 & 28 & 4 & 24 & 18 & 26 \\
\hline Toplam & 21 & 100 & 32 & 100 & 17 & 100 & 70 & 100 \\
\hline \multicolumn{9}{|l|}{ Çiftçilik dışındaki meslek } \\
\hline Tüccar & 1 & 4.8 & - & - & - & - & 1 & 1.4 \\
\hline Esnaf & 1 & 4.8 & - & - & - & - & 1 & 1.4 \\
\hline Memur & 1 & 4.8 & - & - & - & - & 1 & 1.4 \\
\hline Serbest meslek & 3 & 14 & 4 & 13 & 1 & 5.9 & 8 & 12 \\
\hline Yok & 15 & 71 & 28 & 88 & 16 & 94 & 59 & 84 \\
\hline Toplam & 21 & 100 & 32 & 100 & 17 & 100 & 70 & 100 \\
\hline \multicolumn{9}{|l|}{ Sosyal güvence } \\
\hline Var & 10 & 48 & 25 & 78 & 14 & 82 & 49 & 70 \\
\hline Yok & 11 & 52 & 7 & 22 & 3 & 18 & 21 & 30 \\
\hline Toplam & 21 & 100 & 32 & 100 & 17 & 100 & 70 & 100 \\
\hline \multicolumn{9}{|l|}{ Tarımsal örgüt üyeliği* } \\
\hline Ziraat Odası & 7 & 33 & 21 & 66 & 13 & 77 & 41 & 59 \\
\hline Süt Üreticileri Birliği & 9 & 43 & 15 & 47 & 10 & 59 & 34 & 49 \\
\hline Tarım Kredi Kooperatifi & 3 & 14 & 16 & 50 & 10 & 59 & 29 & 41 \\
\hline Damızlık Sığır Yetiştiricileri Birliği & 2 & 9.5 & 3 & 9.4 & 9 & 53 & 14 & 20 \\
\hline Islah Amaçlı Yetiştirici Birlikleri & 1 & 4.8 & 1 & 3.1 & 5 & 29 & 7 & 10 \\
\hline Tarımsal Kalkınma Kooperatifi & - & - & 2 & 6.3 & 4 & 24 & 6 & 8.6 \\
\hline \multicolumn{9}{|c|}{ Süt sığırcılığı yapılmasının esas amacı } \\
\hline Geçimini sağlamak & 12 & 57 & 26 & 81 & 14 & 82 & 52 & 74 \\
\hline Ek gelir elde etmek & 5 & 24 & 4 & 13 & 2 & 12 & 11 & 16 \\
\hline Başka imkânının olmaması & 2 & 9.5 & 2 & 6.2 & 1 & 5.9 & 5 & 7.1 \\
\hline Bağımsız çalışma isteği & 2 & 9.5 & - & - & - & - & 2 & 2.9 \\
\hline Toplam & 21 & 100 & 32 & 100 & 17 & 100 & 70 & 100 \\
\hline
\end{tabular}


İşletmeler büyüdükçe 14 yıl ve üzerinde süt sığırcılığı deneyimine sahip yöneticilerin oranı artmaktadır. Başka mesleği olmayan ve sadece hayvancılık yapanların oranı birinci grupta $\% 71.4$ iken, ikinci ve üçüncü grupta sırasıyla \%87.5 ve \%94.1'dir. İşletmeler büyüdükçe sosyal güvenceye sahip ve Süt Üreticileri Birliği ile Damızlık Sığır Yetiştiricileri Birliği'ne üye yöneticilerin oranı artmaktadır. Süt sığırcılığı yapılmasının esas amacı, ailenin geçimini sağlamak olanların oranı işletmeler ortalamasına göre \%74.3 olup, bu oran üç işletme büyüklük grubunda da en yüksektir (Çizelge 1). Bu sonuç, Koçyiğit ve ark. (2016) tarafından Erzurum ili Hınıs ilçesi için tespit edilen süt sığırcılığını geçim kaynağı olarak yapanların oranına (\%79) yakındır.

Incelenen işletmelerin \%54.3'ünde aile nüfusu 5 ve üzeri kişiden oluşmaktadır. Işletmelerde sadece hayvancılık yapanların oranı \%68.6 iken, diğerleri hayvancılıkla bitkisel üretimi birlikte yapmaktadır. İşletmelerde esas gelir süt ve mamullerinden elde edilmekle birlikte, buzağı ve hayvan gübresi satışı da önemli bir gelir kaynağı olmaktadır. İşletmelerin $\% 80$ 'i öz sermayeyle kurulmuş olup, işletmelerde hayvan sayısı arttıkça öz sermaye oranı azalmaktadır (Çizelge 2).

Çizelge 2. İşletmelere ait özellikler

\begin{tabular}{|c|c|c|c|c|c|c|c|c|}
\hline & \multicolumn{2}{|c|}{ 1. grup } & \multicolumn{2}{|c|}{ 2. grup } & \multicolumn{2}{|c|}{ 3. grup } & \multicolumn{2}{|c|}{$\begin{array}{l}\text { İşletmeler } \\
\text { ortalaması }\end{array}$} \\
\hline & Sayı & (\%) & Sayı & (\%) & Sayı & (\%) & Sayı & (\%) \\
\hline \multicolumn{9}{|l|}{ Aile nüfusu } \\
\hline$<5$ & 12 & 57.1 & 16 & 50.0 & 4 & 23.5 & 32 & 45.7 \\
\hline$\geq 5$ & 9 & 42.9 & 16 & 50.0 & 13 & 76.5 & 38 & 54.3 \\
\hline Toplam & 21 & 100.0 & 32 & 100.0 & 17 & 100.0 & 70 & 100.0 \\
\hline \multicolumn{9}{|l|}{ Üretim faaliyeti } \\
\hline Hayvancilık & 17 & 81.0 & 20 & 62.5 & 11 & 64.7 & 48 & 68.6 \\
\hline Hayvancılık + Bitkisel üretim & 4 & 19.0 & 12 & 37.5 & 6 & 35.3 & 22 & 31.4 \\
\hline Toplam & 21 & 100.0 & 32 & 100.0 & 17 & 100.0 & 70 & 100.0 \\
\hline \multicolumn{9}{|l|}{ Kuruluş sermayesi } \\
\hline Öz sermaye & 20 & 95.2 & 26 & 81.3 & 10 & 58.8 & 56 & 80.0 \\
\hline Öz sermaye + Banka kredisi & 1 & 4.8 & 4 & 12.5 & 3 & 17.7 & 8 & 11.4 \\
\hline Banka kredisi & - & - & 2 & 6.2 & 4 & 23.5 & 6 & 8.6 \\
\hline Toplam & 21 & 100.0 & 32 & 100.0 & 17 & 100.0 & 70 & 100.0 \\
\hline Süt sığırı sayısı (baş) & 4 & - & 12.3 & - & 41.1 & - & 16.8 & - \\
\hline \multicolumn{9}{|l|}{ Ahır kapasitesi kullanım } \\
\hline oranı (\%) & - & 19.5 & - & 29.1 & - & 40.2 & - & 33.3 \\
\hline \multicolumn{9}{|l|}{ Sağım yeri } \\
\hline Var & 3 & 14.3 & 8 & 25.0 & 8 & 47.1 & 19 & 27.1 \\
\hline Yok & 18 & 85.7 & 24 & 75.0 & 9 & 52.9 & 51 & 72.9 \\
\hline Toplam & 21 & 100.0 & 32 & 100.0 & 17 & 100.0 & 70 & 100.0 \\
\hline \multicolumn{9}{|l|}{ Doğumhane } \\
\hline Var & 6 & 28.6 & 17 & 53.1 & 11 & 64.7 & 34 & 48.6 \\
\hline Yok & 15 & 71.4 & 15 & 46.9 & 6 & 35.3 & 36 & 51.4 \\
\hline Toplam & 21 & 100.0 & 32 & 100.0 & 17 & 100.0 & 70 & 100.0 \\
\hline \multicolumn{9}{|l|}{ Buzağı kulübesi } \\
\hline Var & 9 & 42.9 & 14 & 43.7 & 13 & 76.5 & 36 & 51.4 \\
\hline Yok & 12 & 57.1 & 18 & 56.3 & 4 & 23.5 & 34 & 48.6 \\
\hline Toplam & 21 & 100.0 & 32 & 100.0 & 17 & 100.0 & 70 & 100.0 \\
\hline \multicolumn{9}{|l|}{ Revir } \\
\hline Var & 1 & 4.8 & 6 & 18.7 & 3 & 17.6 & 10 & 14.3 \\
\hline Yok & 20 & 95.2 & 26 & 81.3 & 14 & 82.4 & 60 & 85.7 \\
\hline Toplam & 21 & 100.0 & 32 & 100.0 & 17 & 100.0 & 70 & 100.0 \\
\hline \multicolumn{9}{|l|}{ Gezinti alanı } \\
\hline Var & 16 & 76.2 & 27 & 84.4 & 17 & 100.0 & 60 & 85.7 \\
\hline Yok & 5 & 23.8 & 5 & 15.6 & - & - & 10 & 14.3 \\
\hline Toplam & 21 & 100.0 & 32 & 100.0 & 17 & 100.0 & 70 & 100.0 \\
\hline
\end{tabular}


İşletmeler ortalamasına göre \%33.3 olan ahır kapasitesi kullanım oranı, işletme büyüklük gruplarına göre artış göstermektedir. İ̧letmelerin \%27.1'inde sağım yeri, \%48.6'sında doğumhane ve \%51.4'ünde buzağı kulübesi bulunmaktadır. İşletmeler ortalamasına göre reviri olan işletmelerin oranı \%14.3 iken, \%85.7 gibi büyük bir kısmında gezinti alanı vardır
(Çizelge 2). Aydın ilinde yapılan bir araştırmaya göre, bağımsı doğum ünitesi bulunan işletmelerin oranı \%46'dır (Bardakçıoğlu ve ark., 2004). Edirne ilinde yapılan bir araştırmada da, işletmelerin \%6'sında revir, \%96'sında ise gezinti alanı olduğu tespit edilmiştir (Şevik, 2017).

Çizelge 3. Süt sığırcılığıyla ilgili teknik özellikler

\begin{tabular}{|c|c|c|c|c|c|c|c|c|}
\hline & \multicolumn{2}{|c|}{ 1. grup } & \multicolumn{2}{|c|}{ 2. grup } & \multicolumn{2}{|c|}{ 3. grup } & \multicolumn{2}{|c|}{$\begin{array}{l}\text { İşletmeler } \\
\text { ortalaması }\end{array}$} \\
\hline & Sayı & $(\%)$ & Sayı & $(\%)$ & Sayı & $(\%)$ & Sayı & $(\%)$ \\
\hline \multicolumn{9}{|l|}{ Ahır tipi } \\
\hline Bağ|ı duraklı & 20 & 95.2 & 24 & 75.0 & 5 & 29.4 & 49 & 70.0 \\
\hline Serbest duraklı & 1 & 4.8 & 6 & 18.8 & 7 & 41.2 & 14 & 20.0 \\
\hline Serbest & - & & 2 & 6.2 & 5 & 29.4 & 7 & 10.0 \\
\hline Toplam & 21 & 100.0 & 32 & 100.0 & 17 & 100.0 & 70 & 100.0 \\
\hline \multicolumn{9}{|l|}{ Havalandırma yöntemi } \\
\hline Doğal & 21 & 100.0 & 32 & 100.0 & 15 & 88.2 & 68 & 97.1 \\
\hline Mekanik & - & - & - & - & 2 & 11.8 & 2 & 2.9 \\
\hline Toplam & 21 & 100.0 & 32 & 100.0 & 17 & 100.0 & 70 & 100.0 \\
\hline \multicolumn{9}{|l|}{ Hayvan ırkları* } \\
\hline Simental & 14 & 66.7 & 27 & 84.4 & 15 & 88.2 & 56 & 80.0 \\
\hline Holstein & 9 & 42.9 & 18 & 56.3 & 8 & 47.1 & 35 & 50.0 \\
\hline Jersey & 13 & 61.9 & 12 & 37.5 & 7 & 41.2 & 32 & 45.7 \\
\hline Montofon & 5 & 23.8 & 4 & 12.5 & 6 & 35.3 & 15 & 21.4 \\
\hline Yerli kara & 1 & 4.8 & 1 & 3.1 & 1 & 5.9 & 3 & 4.3 \\
\hline Diğer** & - & - & 2 & 6.3 & 1 & 5.9 & 3 & 4.3 \\
\hline \multicolumn{9}{|l|}{ Günlük yemleme sayısı } \\
\hline Bir & 1 & 4.8 & - & - & 2 & 11.8 & 3 & 4.3 \\
\hline İki & 15 & 71.4 & 32 & 100.0 & 14 & 82.3 & 61 & 87.1 \\
\hline Üç & 5 & 23.8 & - & - & 1 & 5.9 & 6 & 8.6 \\
\hline Toplam & 21 & 100.0 & 32 & 100.0 & 17 & 100.0 & 70 & 100.0 \\
\hline \multicolumn{9}{|c|}{ Kesif yemin temin edildiği yer } \\
\hline Yem bayii & 14 & 66.7 & 21 & 65.6 & 11 & 64.7 & 46 & 65.7 \\
\hline Yem bayii + Kendi üretimi & 5 & 23.8 & 9 & 28.1 & 5 & 29.4 & 19 & 27.1 \\
\hline Tarım Kredi Kooperatifi & 2 & 9.5 & 2 & 6.3 & 1 & 5.9 & 5 & 7.2 \\
\hline Toplam & 21 & 100.0 & 32 & 100.0 & 17 & 100.0 & 70 & 100.0 \\
\hline \multicolumn{9}{|l|}{ Sütün başlıca } \\
\hline \multicolumn{9}{|l|}{ değerlendirilme şekli } \\
\hline Süt fabrikasına satış & 6 & 28.6 & 24 & 75.0 & 9 & 52.9 & 39 & 55.7 \\
\hline Doğrudan tüketiciye satış & 5 & 23.8 & 6 & 18.8 & 5 & 29.4 & 16 & 22.9 \\
\hline Aile içi tüketim & 8 & 38.1 & 1 & 3.1 & - & - & 9 & 12.9 \\
\hline Birlik aracılığıyla satış & 2 & 9.5 & 1 & 3.1 & 1 & 5.9 & 4 & 5.7 \\
\hline Kooperatif aracığıyla satış & - & - & - & - & 2 & 11.8 & 2 & 2.8 \\
\hline Toplam & 21 & 100.0 & 32 & 100.0 & 17 & 100.0 & 70 & 100.0 \\
\hline
\end{tabular}

*Birden fazla seçenek işaretlenmiştir. **Shorthorn, Doğu Anadolu KırmızıSı, Güney Anadolu Kırmızısı

İşletmeler ortalamasına göre \%70 ile bağı duraklı ahır tipine sahip işletmeler en fazladır. Ahırlarda doğal yöntemle havalandırma yapan işletmelerin oranı \%97.1 iken, mekanik yolla havalandırma yapanların oranı (\%2.9) oldukça düşüktür. İşletmelerdeki sığır ırklarına bakıldığında simental (\%80), holstein (\%50) ve jerseyin (\%45.7) daha çok tercih edildiği görülmektedir. İncelenen işletmelerde günde iki defa yapılan yemleme (\%87.1) yaygındır. İşletmelerin \%65.7'si yem temininde sadece bayileri tercih ederken, kendi ürettikleri yemle birlikte bayiden yem satın alan işletmeler de (\%27.1) bulunmaktadır (Çizelge 3). Farklı bölgelerde yapılan araştırmalarda da, işletmelerin kullandıkları kesif yemi daha çok satın aldıkları görülmektedir (Boz, 2013; Hozman ve Akçay, 2016; Alkan ve Ünlü, 2019). 
İncelenen işletmelerde üretilen sütün başlıca değerlendirilme şekli olarak, işletmeler ortalamasına göre \%55.7 ile süt fabrikasına satış ilk sırada yer almaktadır. İşletmelerde birlik (\%5.7) ve kooperatif (\%2.8) aracılığıyla süt satışı yapanlar azınlıktadır. Birinci grupta \%38.1 ile aile içi tüketim oranı en yüksek iken, ikinci (\%75) ve üçüncü grupta (\%52.9) süt fabrikasına satış ilk sıradadır (Çizelge 3). İzmir ilinde yapılan bir araştırmada, işletmeler ortalamasına göre süt satışında en yüksek payı $\% 57.9$ ile süt toplayıcısının, \%1.2 ile en düşük payı ise fabrikanın aldığı tespit edilmiştir (Koyubenbe, 2005). Tekirdağ ilinde yapılan benzer bir araştırmada da, üreticilerin $\% 38^{\prime} i$ sütü mandıraya satarken, fabrikaya satanların oranı sadece \%7'dir (Soyak ve ark., 2007).

Süt sığırcılığı uzun vadeli bir faaliyet olduğu için, bu alana yapılan yatırımların başka faaliyetlere dönüştürülmesi oldukça güçtür. Diğer bir ifadeyle süt sığırcılığı yapan işletmelerde kısa dönem için planlama esnekliği bulunmamaktadır (Şahin, 2001). Anket yapılan işletme yöneticilerinin sadece \%37.2'si sığır sayısını artırmayı düşünürken, \%51.4'ünün böyle bir düşüncesi yoktur. Sığır sayısını artırmayı düşünmeyen birinci gruptaki işletmelerde gerekçe olarak ilk sırada işgücü eksikliği (\%45.4) gösterilirken, ikinci (\%52.4) ve üçüncü grupta (\%75) ilk sırayı gelir yetersizliği almaktadır. Süt sığırcılığına devam etmeyi düşünmeyen yöneticilerin oranı işletmeler ortalamasına göre \%11.4 olup, bunun en önemli nedeni \%37.5 ile sermaye kısıtlılı̆ı̆ıır (Çizelge 4). Kars ilinde yapılan bir araştırmada, yöneticilerin $\% 62.5^{\prime} \mathrm{i}$ süt üretimini artırmayı düşündüklerini, geriye kalanı mevcut üretim kapasitesiyle faaliyetlerine devam etmek istediklerini belirtmişlerdir. Aynı araştırmada, yöneticilerin süt üretimini artırmayı istemelerindeki en önemli neden teşvik primi iken, üretimin artırılmasını istememelerinde çoğunlukla süt fiyatının düşük olması gösterilmiştir (Demir ve Aral, 2009). Trakya Bölgesi'nde yapılan bir araştırmada ise, süt sığırcılığından vazgeçmeyi düşünen yöneticilerin oranı \%46.3 olarak tespit edilmiştir (Koç ve Uzmay, 2018).

İncelenen işletmelerde, süt sığırcılığıyla ilgili sorunların başında işletmeler ortalamasına göre süt fiyatındaki istikrarsızlık (\%51.4) gelirken, bunu yem temini (\%41.4) ve pazarlamayla (\%37.1) ilgili sorunlar izlemektedir. Süt fiyatının istikrarsız olmasından \%70.6 ile en fazla üçüncü gruptaki işletmeler etkilenmektedir. İşletme yöneticileri sağım, mekanizasyon ve yem hazırlama konularında çok fazla sorun yaşamadıklarını belirtmişlerdir (Çizelge 4). Giresun ilinde yapılan bir araştırmada, süt sığırcılığı yapan işletmelerin en fazla yem fiyatının yüksekliği (\%93.6) ve süt fiyatının düşük olması (\%45) konularında sorun yaşadıkları tespit edilmiştir (Tugay ve Bakır, 2009). Doğu Akdeniz Bölgesi'nde yapılan benzer bir araştırmaya göre, süt sığırcılığı yapan işletmelerdeki sorunların başında yem fiyatının yüksekliği ve hayvancılığa yönelik desteklerin yetersiz olması gelmektedir (Boz, 2013). Ağrı ilinde yapılan bir araştırmada, süt sığırcılığında en büyük sorun olarak hayvan hastalıkları (\%49.58) gösterilirken (Bakan ve Aydın, 2016), İzmir ilinde yapılan bir araştırmada süt sığırcılığı üretim maliyetinin yüksek olması (\%89.55) en önemli sorun olarak belirtilmiştir (Torgut ve ark., 2019).

\section{Sonuç ve Öneriler}

İncelenen işletmelerin büyük bir kısmında süt sığırcılığıyla birlikte bitkisel üretim faaliyetlerine de yer verilmektedir. İşletmelerde hayvanlar için gerekli kesif ve kaba yem ihtiyacının bir bölümü bitkisel üretimden sağlanırken, hayvanlardan elde edilen gübre ise bitkisel üretimde kullanılmaktadır. İşletmelerin önemli bir kısmı intiyaç duydukları kesif yemi satın almaktadır. Ancak bitkisel ve hayvansal üretimin birbirine yardımcı olan ve birbirini tamamlayan faaliyetler olduğu gerçeğinden hareketle, yem ihtiyacının büyük ölçüde işletmede üretilmesi önemli katma değer artışı sağlayacaktır. Ayrıca bitkisel üretim ve hayvancılık birlikte yapıldığında, işletmelerdeki aile işgücü daha etkin kullanılacağından atıl işgücü oranı da azalmış olacaktır.

Süt sığırcılığı işletmeleri arasında yapısal özellikler yönünden önemli farklılıklar söz konusudur. $\mathrm{Bu}$ duruma, işletme yöneticilerindeki teknik bilginin yetersiz olmasının da etkili olduğu söylenebilir. Halbuki yöneticilerin yeterli teknik bilgiye sahip olmasıyla, kaynaklar etkin kullanılacağından işletmelerin daha rantabl çalışmaları mümkün olacaktır. 
Çizelge 4. Süt sığırcılığıyla ilgili uygulamalar

\begin{tabular}{|c|c|c|c|c|c|c|c|c|}
\hline & \multicolumn{2}{|c|}{ 1. grup } & \multicolumn{2}{|c|}{ 2. grup } & \multicolumn{2}{|c|}{ 3. grup } & \multicolumn{2}{|c|}{$\begin{array}{l}\text { İşletmeler } \\
\text { ortalaması }\end{array}$} \\
\hline & Sayı & (\%) & Sayı & (\%) & Sayı & (\%) & Sayı & (\%) \\
\hline \multicolumn{9}{|c|}{ İşletmeyle ilgili yatırım yapma } \\
\hline \multicolumn{9}{|c|}{ Sığır sayısını artırmayı } \\
\hline düşünüyor & 6 & 28.6 & 8 & 25.0 & 12 & 70.6 & 26 & 37.2 \\
\hline \multicolumn{9}{|l|}{ Sığır sayısını artırmayı } \\
\hline düşünmüyor & 11 & 52.4 & 21 & 65.6 & 4 & 23.5 & 36 & 51.4 \\
\hline \multicolumn{9}{|l|}{ Süt sığırcılığına devam } \\
\hline etmeyi düşünmüyor & 4 & 19.0 & 3 & 9.4 & 1 & 5.9 & 8 & 11.4 \\
\hline Toplam & 21 & 100.0 & 32 & 100.0 & 17 & 100.0 & 70 & 100.0 \\
\hline \multicolumn{9}{|l|}{ Sığır sayısını artırmayı } \\
\hline \multicolumn{9}{|l|}{ düşünmeme nedeni } \\
\hline Gelir yetersizliği & 3 & 27.3 & 11 & 52.4 & 3 & 75.0 & 17 & 47.2 \\
\hline İşgücü eksikliği & 5 & 45.4 & 5 & 23.8 & - & - & 10 & 27.8 \\
\hline Sermaye yetersizliği & 3 & 27.3 & 5 & 23.8 & 1 & 25.0 & 9 & 25.0 \\
\hline Toplam & 11 & 100.0 & 21 & 100.0 & 4 & 100.0 & 36 & 100.0 \\
\hline \multicolumn{9}{|c|}{$\begin{array}{l}\text { Süt sığırcılığına devam etmeyi } \\
\text { düşünmeme nedeni }\end{array}$} \\
\hline Sermaye kısıtlılığı & 1 & 25.0 & 2 & 66.7 & - & - & 3 & 37.5 \\
\hline Gelir yetersizliği & - & - & 1 & 33.3 & 1 & 100.0 & 2 & 25.0 \\
\hline \multicolumn{9}{|l|}{ Hayvan bakımındaki } \\
\hline zorluklar & 2 & 50.0 & - & - & - & - & 2 & 25.0 \\
\hline İş gücü eksikliği & 1 & 25.0 & - & - & - & - & 1 & 12.5 \\
\hline Toplam & 4 & 100.0 & 3 & 100.0 & 1 & 100.0 & 8 & 100.0 \\
\hline \multicolumn{9}{|c|}{ Süt sığırcılığıyla ilgili sorunlar* } \\
\hline Süt fiyatındaki istikrarsızlık & 10 & 47.6 & 14 & 43.8 & 12 & 70.6 & 36 & 51.4 \\
\hline Yem temini & 11 & 52.4 & 11 & 34.4 & 7 & 41.2 & 29 & 41.4 \\
\hline Sütün pazarlanması & 9 & 42.9 & 11 & 34.4 & 6 & 35.3 & 26 & 37.1 \\
\hline Süt verimi & 7 & 33.3 & 4 & 12.5 & 3 & 17.6 & 14 & 20.0 \\
\hline Yem kalitesi & 6 & 28.6 & 3 & 9.4 & 1 & 5.9 & 10 & 14.3 \\
\hline Hayvan hastalıkları & 3 & 14.3 & 3 & 9.4 & 3 & 17.6 & 9 & 12.9 \\
\hline Kredi temini & 3 & 14.3 & - & - & 3 & 17.6 & 6 & 8.6 \\
\hline Mekanizasyon & 2 & 9.5 & 1 & 3.1 & 2 & 11.8 & 5 & 7.1 \\
\hline Yem hazırlama & 1 & 4.8 & 4 & 12.5 & - & - & 5 & 7.1 \\
\hline Sağım & 1 & 4.8 & 3 & 9.4 & - & - & 4 & 5.7 \\
\hline
\end{tabular}

*Birden fazla seçenek işaretlenmiștir

İşletmelerde modern yetiştiricilik yöntemlerinin kullanılması, ekonomik ve fiziksel koşullardaki iyileştirmelerle sağlanabilir. İşletmelerin modern bir yapıya dönüşmesinde, tarımsal eğitim çalışmalarının önemi büyüktür. Eğitimlerde süt sığırcılığıyla ilgili verilecek teknik bilgiler, ürünlerde verim düşüklüğü ve kalite sorununun çözümünde etkili olacaktır. Aynı zamanda üretilen her ürün için etkin bir pazarlama ağının kurulması, sürdürülebilir işletmecilik için kaçınılmaz bir gerekliliktir. Öyle ki araştırma bölgesinde özellikle küçük işletmelerde bireysel pazarlamanın yaygın olması, güçlü rekabet koşullarında büyük işletmelere karşı pazarlık gücünü azaltmaktadır. $\mathrm{Bu}$ nedenle bölgede aktif olarak çalışacak üretici örgütlerinin kurulması, girdilerin daha ucuz fiyatla satın alınması ve ürünlerin ise daha yüksek fiyattan satılması açısından son derece önemlidir.

Süt sığırcılığı işletmelerinin ekonomik performansı, büyük ölçüde süt ve mamulleri satışından elde edilen gelire bağlıdır. Süt fiyatında yıl içinde meydana gelen büyük dalgalanmalar ekonomik istikrarsızlığa neden olabilmektedir. Araştırma sonuçları da, süt sığırcılığı işletmelerinde karşılaşılan en önemli sorunun süt fiyatındaki istikrarsızlık olduğunu göstermektedir. Diğer taraftan süt sığırcılığı yapan küçük işletmelerin, ürünlerini yakın il ve ilçe merkezlerinde kurulan pazarlar dışında pazarlama imkânlarının kısıtlı olması, ürünlerin taşınması esnasında değer kaybetmesi, hatta bozulmayla tamamen yok olması gibi önemli sorunları ortaya çıkarmaktadır. Süt sığırcılığı yapan işletmeler, sadece kaliteli süt ve mamullerinin üretilmesi konusunda değil, aynı 
zamanda bu ürünlerin sağlıklı bir şekilde tüketiciye ulaştırılması konusunda da sorumluluk taşımaktadır. Bunun için, modern tesislerde ve hijyenik koşullarda üretilen sütün piyasaya sunulması gerekir. Bu bağlamda süt üreticilerinin gıda güvenliği konusundaki bilinç düzeylerinin artırılması önemli olmakla birlikte, bunun tek başına yeterli olduğu söylenemez. Zira modern işletmeciliğin gerektirdiği teknik altyapının sağlanması için, işletmelerde yeterli sermayenin varlığı ile bunun etkin şekilde kullanılması gerçeği göz ardı edilmemelidir.

İncelenen işletmelerde süt sığırcılığına devam etmeyi düşünmeyenler, daha çok sermaye ve gelir yetersizliğine vurgu yapmışlardır. Süt fiyatının artması, gelir artışıyla birlikte üreticiye işletmesini geliştirme konusunda yeni yatırımlar yapma imkânı verecektir. Ancak burada esas hedef, tüketicileri cezalandıran bir fiyat artışı yerine, aracıların payını azaltarak üretici gelirinin artırılması olmalıdır. İşletmelerde üretim teknolojisinin iyileştirilmesine yönelik verilecek teknik ve ekonomik desteklerle, işletmelerin büyümeleri sağlanacağı gibi makro açıdan ülke ekonomisine olan katkıları da artırılmış olacaktır. Süt sığırcılığı yapan işletmelerdeki mevcut sorunların kısa zamanda çözümü, devlet tarafından verilecek desteklerin yanında, üreticilerin aktif katılımlarıyla gerçekleştirilecek örgütlenme hareketiyle mümkün olacaktır.

\section{Kaynaklar}

Alkan, S. ve Ünlü, H. 2019. Giresun ilindeki sığırcılık işletmelerinin genel yapısının belirlenmesi. Mediterranean Agricultural Sciences, 32 (1): 109-115.

Anonim, 2018a. (http://www.zmo.org.tr) (Erişim tarihi: 14.05.2020).

Anonim, 2018b. http://www.tuik.gov.tr, (Erişim tarihi: 14.05.2020).

Anonim, 2018c. (http://zmo.org.tr) (Erişim tarihi: 14.05.2020).

Bakan, Ö. ve Aydın, R. 2016. Ağrı ili süt sığırcılığı işletmelerinin sosyo-ekonomik özellikleri. Atatürk Üniversitesi Ziraat Fakültesi Dergisi, 47 (2): 113-122.

Bakır, G. ve Kibar, M. 2019. Muş ilinde bulunan süt sığırcılığı işletmelerinin bazı yapısal özelliklerinin crosstab analiziyle belirlenmesi. Kahramanmaraş Sütçü Imam Üniversitesi Tarım ve Doğa Dergisi, 22 (4): 609-619.

Bardakçıoğlu, H.E., Türkyılmaz, M.K. ve Nazlıgül, A. 2004. Aydın ili süt sığırcılık işletmelerinde kullanılan barınakların özellikleri üzerine bir araştırma. Istanbul Üniversitesi Veteriner Fakültesi Dergisi, 30 (2): 51-62.

Boz, ì. 2013. Doğu Akdeniz Bölgesi'nde süt sığırcılığı yapan işletmelerin yapısı, sorunları ve çözüm önerileri. Kahramanmaraş Sütçü Imam Üniversitesi Doğa Bilimleri Dergisi, 16 (1): 24-32.

Can, M.F. 2018. Türkiye hayvancılık politikalarının $A B$ ile etkileşimi ve olası sonuçları. Atatürk Üniversitesi Veteriner Bilimleri Dergisi, 13 (2): 242-250.

Daş, A., İnci, H., Karakaya, E. ve Şengül, A.Y. 2014. Bingöl ili damızlık sığır yetiştiricileri birliğine bağlı sığırcılık işletmelerinin mevcut durumu. Türk Tarım ve Doğa Bilimleri Dergisi, 1 (3): 421-429.

Demir, P. ve Aral, S. 2009. Kars ilinde faaliyet gösteren süt sığırcılık işletmelerinin karşılaştıkları sorunlar ve çözüm önerileri. Veteriner Hekimler Derneği Dergisi, 80 (3): 17-22.

Hozman, S.B. ve Akçay, H. 2016. Sivas ili damızlık sığır yetiştiricileri birliğine üye süt sığırcılığı işletmelerinin bazı teknik ve ekonomik özellikleri. Tarım Ekonomisi Dergisi, 22 (1): 57-65.

Kaygısız, A., Tümer, R., Orhan, H. ve Vanlı, Y. 2010. Kahramanmaraş ili süt sığırcılık işletmelerinin yapısal özellikleri 4 . işletmecilerin sosyal ve kültürel durumları. Atatürk Üniversitesi Ziraat Fakültesi Dergisi, 41 (1): 39-44.

Koç, G. ve Uzmay, A. 2018. Süt sığırcılığı işletmelerinde üreticilerin kooperatif kanalıyla süt pazarlama olasılığını etkileyen faktörler: Trakya Bölgesi örneği. Tarım Ekonomisi Dergisi, 24 (2): 203-214.

Koçyiğit, R., Diler, A., Yanar, M., Güler, O., Aydın, R. ve Avcı, M. 2016. Süt sığırcılığı işletmelerinde hayvan sağlığı, veteriner sağlık hizmetleri ve yetiştirici memnuniyeti: Erzurum ili Hınıs ilçesi örneği. Türk Tarım ve Doğa Bilimleri Dergisi, 3(1): 24-32.

Koyubenbe, N. 2005. İzmir ili Ödemiş ilçesinde süt sığırcılığının geliştirilmesi olanakları üzerine bir araştırma. Hayvansal Üretim, 46 (1): 8-13.

Özyürek, S., Koçyiğit, R. ve Tüzemen, N. 2014. Erzincan ilinde süt sığırcılığı yapan işletmelerin yapısal özellikleri: Çayırlı 
ilçesi örneği. Tekirdağ Ziraat Fakültesi Dergisi, 11 (3): 19-26.

Saçlı, Y. 2007. AB'ye uyum sürecinde hayvancılık sektörünün dönüşüm ihtiyacı. T.C. Başbakanlık Devlet Planlama Teşkilat, Uzmanlık tezi.

Soyak, A., Soysal, M.I. ve Gürcan, E.K. 2007. Tekirdağ ili süt sığırcılığı işletmelerinin yapısal özellikleri ve bu işletmelerdeki siyah alaca süt sığırlarının çeşitli morfolojik özellikleri üzerine bir araştırma. Tekirdağ Ziraat Fakültesi Dergisi, 4 (3): 297-305.

Şahin, K. 2001. Kayseri ilinde süt sığırcılığı yapan işletmelerin yapısal özellikleri ve pazarlama sorunları. Yüzüncü Yıl Üniversitesi Ziraat Fakültesi Tarım Bilimleri Dergisi, 11 (1): 79-86.

Şeker, I.,, Tasalı, H. ve Güler, H. 2012. Muş ilinde sığır yetiştiriciliği yapılan işletmelerin yapısal özellikleri. Fırat Üniversitesi
Sağlık Bilimleri Veteriner Dergisi, 26 (1): 9-16.

Şevik, T. 2017. Edirne İli Lalapaşa Illçesi Süt Sığırcılığı Eğitiminin Tarımsal Yayım Açısından Değerlendirilmesi. Namık Kemal Üniversitesi, Fen Bilimleri Enstitüsü, Tarım Ekonomisi Anabilim Dalı, Yüksek lisans tezi, Tekirdağ.

Torgut, E., Annayev, S., Örmeci Kart, M.Ç. ve Türkekul, B. 2019. Süt sığırcılığı yapan işletmelerin genel yapısı, sorunları ve çözüm önerileri: İzmir ili Ödemiş ve Tire ilçeleri örneği. Tarım Ekonomisi Dergisi, 25 (1): 87-95.

Tugay, A. ve Bakır, G. 2009. Giresun yöresindeki süt sığırcılığı işletmelerinin yapısal özellikleri. Atatürk Üniversitesi Ziraat Fakültesi Dergisi, 40 (1): 37-47.

Yamane, T. 1967. Elemantary Sampling Theory. Printice Hall Inc. Englewood Cliffs, Nt. 